\title{
$\beta 3$-adrenergic receptor gene, body mass index, bone mineral density and fracture risk in elderly men and women: the Dubbo Osteoporosis Epidemiology Study (DOES)
}

\author{
Claire Y Wang ${ }^{\dagger 1}$, Nguyen D Nguyen ${ }^{\dagger 1}$, Nigel A Morrison ${ }^{3}$, John A Eisman ${ }^{1,2}$, \\ Jacqueline R Center ${ }^{1}$ and Tuan V Nguyen*1,2
}

\begin{abstract}
Address: ${ }^{1}$ Bone and Mineral Research Program, Garvan Institute of Medical Research, St Vincent's Hospital, University of New South Wales, Sydney, NSW, Australia, ${ }^{2}$ Faculty of Medicine, University of New South Wales, Sydney, NSW, Australia and ${ }^{3}$ School of Medical Science, Griffith University, QLD, Australia

Email: Claire Y Wang - iamclairewang@hotmail.com; Nguyen D Nguyen - n.nguyen@garvan.org.au;

Nigel A Morrison - n.morrison@griffith.edu.au; John A Eisman - j.eisman@garvan.org.au; Jacqueline R Center - j.center@garvan.org.au;

Tuan V Nguyen* - t.nguyen@garvan.org.au

* Corresponding author †Equal contributors
\end{abstract}

Published: 05 July 2006

BMC Medical Genetics 2006, 7:57 doi:10.1 I86/147|-2350-7-57
Received: 3I March 2006

Accepted: 05 July 2006

This article is available from: http://www.biomedcentral.com/147I-2350/7/57

(c) 2006 Wang et al; licensee BioMed Central Ltd.

This is an Open Access article distributed under the terms of the Creative Commons Attribution License (http://creativecommons.org/licenses/by/2.0), which permits unrestricted use, distribution, and reproduction in any medium, provided the original work is properly cited.

\begin{abstract}
Background: Recent studies have suggested that the Arg allele of $\beta 3$-adrenergic receptor (ADRB3) gene is associated with body mass index (BMI), which is an important predictor of bone mineral density (BMD) and fracture risk. However, whether the ADRB3 gene polymorphism is associated with fracture risk has not been investigated. The aim of study was to examine the interrelationships between ADRB3 gene polymorphisms, BMI, BMD and fracture risk in elderly Caucasians.
\end{abstract}

Methods: Genotypes of the ADRB3 gene were determined in 265 men and 446 women aged 60+ in 1989 at entry into the study, whose BMD were measured by DXA (GE Lunar, WI USA) at baseline. During the follow-up period (between 1989 and 2004), fractures were ascertained by reviewing radiography reports and personal interviews.

Results: The allelic frequencies of the Trp and the Arg alleles were 0.925 and 0.075 respectively, and the relative frequencies of genotypes Trp/Trp, Trp/Arg and Arg/Arg 0.857, 0.138 and 0.006 respectively. There was no significant association between $B M I$ and ADRB3 genotypes $(p=0.10$ in women and $p=0.68$ in men). There was also no significant association between ADRB3 genotypes and lumbar spine or femoral neck BMD in either men and women. Furthermore, there were no significant association between ADRB3 genotypes and fracture risk in both women and men, either before or after adjusting for and, BMD and BMI.

Conclusion: The present data suggested that in Caucasian population the contribution of ADRB3 genotypes to the prediction of BMI, BMD and fracture risk is limited. 


\section{Background}

Osteoporosis and obesity are two common disorders that affect a large number of elderly in the general population [1-3]. Approximately $30 \%$ of women and $12 \%$ of men are affected by osteoporosis or low bone mass at some point during life [4]. Moreover, about 31\% of elderly men and $35 \%$ of elderly women are classified as having obesity in the US [5]. Several lines of epidemiologic evidence suggest that the two disorders may be inversely associated, with obese individuals having higher bone mineral density (BMD) and reduced risk of fracture than non-obese individuals [6-11]. Indeed, it has been well-known that between $23 \%$ and $47 \%$ variance of BMD in the general population can be "explained" by the variation in body mass index (BMI) [12,13], making BMI one of the most robust and consistent predictors of BMD [14]. Both body weight (or BMI) and BMD are partly genetically determined. Twin studies have suggested that genetic factors may account for up to $80 \%$ of the BMD variance [15-17]. Likewise, between 43 to $70 \%$ of BMI variance is attributable to genetic factors $[18,19]$. Under the hypothesis of shared genetic effects, a gene that is associated with BMI may also protect against osteoporosis.

The variation in BMD is mainly attributable to genetic factors $[16,17,20]$ and the liability to osteoporotic fracture is also partly determined by genetic factor [21-23]. Experimental evidence suggested that $\beta 3$-adrenergic stimulation can induce expression of osteoclast differentiation factor in osteoblast cells, leading to a stimulation of osteoclastogenesis [24]. Moreover, the activation of $\beta 3$-adrenergic receptors on two osteoblast-like cells can cause bone resorption in intact mouse calvariae [25]. In epidemiological studies, the $\beta 3$-adrenergic receptor (ADRB3) polymorphisms have been found to be associated with BMI [26] and BMD [27]. However, such associations, while largely found in the Japanese population, have not been well studied in Caucasian populations. Moreover, the association between ADRB3 polymorphisms and fracture risk, the ultimate outcome of osteoporosis has not been reported. The present study was aimed at examining the inter-relationships between ADRB3 gene polymorphisms, body mass index, bone mineral density and fracture risk in a well-defined sample of elderly Caucasians.

\section{Methods}

\section{Study design and setting}

The present study was part of the Dubbo Osteoporosis Epidemiology Study (DOES), of which the details of study design and protocols have been described previously [2830]. Briefly, DOES is a community-based, epidemiological study, where participants were recruited from the Dubbo city, a semi-urban city $400 \mathrm{~km}$ northwest of Sydney, Australia, with a population of approximately 32000 people, 98.6\% Caucasian, of whom 1581 men and 2095 women were aged 60 years or above in 1989. Dubbo's relative isolation in terms of medical care allows virtually complete ascertainment of all fractures. From 1993, blood samples were collected from individuals who volunteer to donate at initial visits or follow-up visits. Our present study reports data on a random sample of 446 women and 265 men aged 60 years or above in 1989, who had consented to donate blood for DNA analysis.

\section{Measurements}

After obtaining written informed consent, participants were interviewed by a trained research nurse at initial and subsequent visits at approximately 2-year intervals. A structured questionnaire was used to collect data including age, anthropometric variables, life style and clinical data [31]. Bone mineral density $\left(\mathrm{g} / \mathrm{cm}^{2}\right)$ was measured at the lumbar spine and femoral neck by dual-energy X-ray absorptiometry (DXA) using a Lunar DPX-L densitometer (GE Lunar, WI. USA). The measurement was performed at the same visit or within one month of the blood sample collection in $99 \%$ of cases. In the cases in which the blood was taken at a time other than the scheduled visit, the BMD used was that closest to the time of blood collection.

\section{Ascertainment of fracture}

The incidence of fracture was ascertained during the study period (1989-2004) by radiologist's report and confirmed by personal interview. Only low trauma fractures were included (i.e. a fall from the standing height or less). Fractures due to motor vehicle accidents or pathological conditions were excluded. Fractures were categorised into 4 groups: hip, symptomatic vertebral, Colles' and other fractures.

\section{Genotyping}

Genomic DNA was extracted from peripheral blood leukocytes. The ADRB3 polymorphism was determined by polymerase chain reaction (PCR) performed with $20 \mathrm{ng}$ of genomic DNA with upstream primer 5' CCA GTG GGC TGC CGA GGG 3' and downstream primer 5' GCC AGT GGC GCC CAA CGG 3' [32]. The amplification products were digested with the restriction enzyme BstOI (Promega, Madison, WI, USA) and genotyped as $\operatorname{Tr} p$ homozygotes $(\operatorname{Tr} p / \operatorname{Tr} p)$, heterozygotes (Trp/Arg), or Arg homozygotes (Arg/Arg). This Trp64Arg polymorphism has been commonly used in genetic epidemiological studies.

\section{Statistical analysis}

Alleles were counted and the genotype frequencies of the polymorphism was checked for Hardy-Weinberg equilibrium (HWE) by the likelihood Chi-square statistic [33]. The baseline characteristics of the subjects in the fracture group and the non-fracture group were compared using descriptive statistical tests with appropriate techniques (e.g. Student's t-test for normally distributed variables, 
such as BMI and BMD) and Chi-square (for categorical data), depends on the distribution of the variables. The association between each polymorphism and BMD or BMI was analyzed by the analysis of covariance (ANCOVA) model taking into account the effects of potential covariates such as age, weight and life-style factors.

In order to quantify the risk of sustaining a fracture in relation to ADRB3 genotypes, subjects were grouped into those with Arg allele and those without Arg allele. The association was analyzed by the logistic regression model taking into account the effects of potential confounders.

In order to determine the association between BMI and ADRB3 polymorphisms, a Bayesian approach was used [34,35]. In the Bayesian analysis, the currently observed data are combined with known data to derive a "posterior distribution" with credible interval. In the present study, a prior mean difference $\left(M_{0}\right)$ in BMI between subjects with and without $\mathrm{Arg}$ allele was obtained from a meta-analysis [26] with a $95 \%$ confidence interval $(95 \% \mathrm{CI})$ being $\left(\mathrm{L}_{0}\right.$, $\left.\mathrm{U}_{0}\right)$, from which the standard deviation $\left(\mathrm{SD}_{0}\right)$ for the prior distribution was calculated as follow: $\mathrm{SD}_{0}=\left(\mathrm{U}_{0}-\mathrm{L}_{0}\right)$ / 3.92 , assuming the difference follows the normal distribution. In order to construct a posterior distribution with mean $\left(\mathrm{M}_{\mathrm{p}}\right)$ and standard deviation $\left(\mathrm{SD}_{\mathrm{p}}\right)$, the prior distribution was combined with the present study's data, which has a mean of $\mathrm{M}_{\mathrm{d}}$ and standard deviation of $\mathrm{SD}_{\mathrm{d}}$. The posterior mean and SD are: $\mathrm{M}_{\mathrm{p}}=\left(\mathrm{SD}_{\mathrm{p}}\right)^{2}\left[\left(\mathrm{M}_{0} / \mathrm{SD}_{0}{ }^{2}\right)+\left(\mathrm{M}_{\mathrm{d}} / \mathrm{SD}_{\mathrm{d}}\right.\right.$ $\left.\left.{ }^{2}\right)\right]$ and $\mathrm{SD}_{p}=1 / \sqrt{\left(1 / S D_{0}\right)^{2}+\left(1 / S D_{d}\right)^{2}}$. Thus, the posterior mean is a weighted average of two estimates (prior mean and the present study's mean) with the weight being the inverse variances. The analysis was conducted via the SAS system [36].

\section{Results}

\section{Characteristics of study subjects}

In total, 446 women and 265 men who had been followed-up for the median of 13.2 years (interquartile range, IQR: 10.4-14.1) and 12.9 years (IQR: 9.0-14.0) for women and men, respectively.

The frequencies of the Trp/Trp, Trp/Arg and Arg/Arg genotypes were $385(86.3 \%), 58(13.0 \%)$ and $3(0.7 \%)$ respectively for women, and $224(84.5), 40(15.1 \%)$ and 1 $(0.4 \%)$ respectively for men. In both sexes, the allelic frequencies of Trp allele and $\mathrm{Arg}$ allele were 0.925 and 0.075 respectively. Because the frequency of Arg allele was low in the population, individuals with Trp/Arg and Arg/Arg genotypes were considered as one group. The overall geno- type distribution in the study subjects was in HardyWeinberg equilibrium $\left(\chi^{2}=0.007, \mathrm{p}=0.98\right)$.

Clinical characteristics of subjects were stratified by the presence or absence of $\mathrm{Arg}$ allele (Table 1). The presence of Arg allele in women is associated with a $0.25 \mathrm{SD}$ increase in body weight, but this difference was not statistically significant $(\mathrm{p}=0.08)$. In both women and men, there were no statistically significant differences between Arg allele carriers and non-carriers in terms of anthropometric characteristics and lifestyle factors.

\section{ADRB3 genotypes and BMI}

In the present study, there was no significant association between ADRB3 genotypes and BMI. The overall mean difference in BMI for Arg carriers versus non-carriers was $0.54 \mathrm{~kg} / \mathrm{m}^{2}$ (95\% CI: $\left.-0.35,1.44 ; \mathrm{P}=0.23\right)$, or $0.13 \mathrm{SD}$. In a previous meta-analysis [26], $\mathrm{Arg}$ carriers had higher BMI than non-Arg carriers by $0.30(95 \% \mathrm{CI}, 0.13-0.47) \mathrm{kg} / \mathrm{m}^{2}$ as indicated in the prior distribution (Figure 1). After updating the previous data with the present study's data, the posterior distribution showed that BMI in the Arg allele carriers are, on average, $0.31 \mathrm{~kg} / \mathrm{m}^{2}(95 \% \mathrm{CI}, 0.14-$ 0.48 ) higher than non-Arg carriers.

\section{ADRB3 genotypes and $B M D$}

In multiple regression analysis of BMD measurements at both lumbar spine and femoral neck (Table 2), there were no significant associations between ADRB3 and BMD at both LS and FN sites. However, in both women and men, age and smoking history were negatively associated with femoral neck BMD, and BMI was positively associated with lumbar spine and femoral neck BMD. Although increased physical activity was not associated with BMD measured at femoral neck, it was positively associated with lumbar spine BMD. Collectively these factors (age, BMI, smoking history, calcium intake, physical activity and ADRB3 genotypes) explained about $30 \%$ and $12 \%$ of variances in femoral neck BMD in women and men respectively.

\section{ADRB3 genotypes and fracture risk}

During the follow up period, 173 women and 49 men had sustained at least one osteoporotic fracture. In women, the most common fracture site was distal radius (Colles' fracture) with an incidence rate of $24 \%$ of all the cases, followed by vertebral $(23 \%)$ and hip $(14 \%)$. In men, the most common fracture site was vertebrae $(41 \%)$, followed by hip (16\%) and ribs (14\%). For both women and men, fracture individuals were older, weighed less, and had lower BMD at both femoral neck and lumbar spine compared to their non-fracture counterparts (Table 3). However, there was no significant difference between the fracture group and non-fracture group in terms of calcium intake, physical activity and smoking history. 
Table I: Baseline characteristics of subjects stratified by ADRB3 genotype

\begin{tabular}{|c|c|c|c|c|}
\hline & $\operatorname{Trp} / \operatorname{Trp}$ & $\operatorname{Trp} / \operatorname{Arg}+\operatorname{Arg} / \operatorname{Arg}$ & Standardized difference & $P$ value \\
\hline Women (N) & 385 & 61 & & \\
\hline Age $(y)$ & $71 \pm 8$ & $71 \pm 6$ & 0.00 & 0.47 \\
\hline Weight (kg) & $64 \pm 12$ & $67 \pm 13$ & 0.25 & 0.08 \\
\hline Height $(\mathrm{cm})$ & $160 \pm 6$ & $160 \pm 6$ & 0.00 & 0.90 \\
\hline $\mathrm{BMI}\left(\mathrm{kg} / \mathrm{m}^{2}\right)$ & $25 \pm 5$ & $26 \pm 5$ & 0.20 & 0.10 \\
\hline Ca intake (mg/day) & $644 \pm 372$ & $650 \pm 355$ & 0.02 & 0.90 \\
\hline Physical activity (METs) & $80 \pm 30$ & $82 \pm 23$ & 0.07 & 0.54 \\
\hline Femoral neck BMD $\left(\mathrm{g} / \mathrm{cm}^{2}\right)$ & $0.76 \pm 0.13$ & $0.79 \pm 0.13$ & 0.23 & 0.24 \\
\hline Lumbar spine BMD $\left(\mathrm{g} / \mathrm{cm}^{2}\right)$ & $1.00 \pm 0.18$ & $1.04 \pm 0.21$ & 0.22 & 0.11 \\
\hline Age of menopause (y) & $47 \pm 7$ & $46 \pm 7$ & -0.14 & 0.52 \\
\hline Current/ex smoker $\mathrm{a}, \mathrm{b}$ & $106(27.5)$ & $22(36.1)$ & & 1.87 \\
\hline Men (N) & 224 & 41 & & \\
\hline Age $(y)$ & $70 \pm 6$ & $68 \pm 5$ & -0.34 & 0.12 \\
\hline Weight (kg) & $78 \pm 12$ & $77 \pm 13$ & -0.08 & 0.46 \\
\hline Height $(\mathrm{cm})$ & $174 \pm 6$ & $173 \pm 8$ & -0.16 & 0.77 \\
\hline BMI $\left(\mathrm{kg} / \mathrm{m}^{2}\right)$ & $26 \pm 3$ & $26 \pm 4$ & 0.00 & 0.68 \\
\hline $\mathrm{Ca}$ intake (mg/day) & $657 \pm 367$ & $732 \pm 317$ & 0.21 & 0.23 \\
\hline Physical activity (METs) & $76 \pm 49$ & $72 \pm 48$ & -0.08 & 0.69 \\
\hline Femoral neck BMD $\left(\mathrm{g} / \mathrm{cm}^{2}\right)$ & $0.92 \pm 0.15$ & $0.93 \pm 0.15$ & 0.07 & 0.63 \\
\hline Lumbar spine BMD $\left(\mathrm{g} / \mathrm{cm}^{2}\right)$ & $1.26 \pm 0.21$ & $1.24 \pm 0.24$ & -0.09 & 0.59 \\
\hline Current/ex smoker a,b & $122(54.5)$ & $25(61.0)$ & & 0.59 \\
\hline
\end{tabular}

Values are mean $\pm S D$, otherwise specified; $P$ values were calculated using unpaired $t$-test, otherwise specified. BMI, body mass index; Ca, calcium; METs, metabolic equivalents.

${ }^{\text {a } N(\%) ; ~}{ }^{\circ}$ Chi-square test.

The distribution of ADRB3 genotypes in fracture and nonfracture subjects is shown in Table 4. Women with the Arg/Arg and Trp/Arg genotypes had lower incident rate of any fracture than those with the Trp/Trp genotype, but the difference was not statistically significant $(32.8 \%$ vs. $39.7 \%, \mathrm{p}=0.30$ ). This non-significant association was observed for all specific fracture sites. However, in men, individuals with the Arg/Arg and Trp/Arg genotypes had higher incident rate of any fracture than those with the $\operatorname{Trp} / \operatorname{Tr} p$ genotype (22.0\% vs. $17.9 \%)$; the difference was also not statistically significant ( $\mathrm{p}=0.53)$. After adjusting for age, $\mathrm{BMI}$ and/or BMD, the associations between the ADRB3 polymorphism and fracture risk in women and men were not statistically significant (Table 5). There were no interaction effects between ADRB3 genotypes and age on fracture risk (data not shown).

\section{Discussion}

Obesity is associated with increased BMD and reduced fracture risk $[11,37]$. Studies on polymorphisms of the ADRB3 gene and their association with BMD have been reported in the Japanese population $[27,38]$, but not in Caucasians. The present data further suggested that there was no significant association between ADRB3 genotypes and fracture risk in a Caucasian population.

The ADRB3 genotypes have largely been investigated for association with BMI in the Japanese population, from whom a significant association has been reported. The association was characterised by individuals with the $\mathrm{Arg}$ allele having higher BMI than individuals without the Arg allele. In this study, individuals with the Arg allele also had higher BMI than individuals without the Arg allele, but the difference did not reach statistical significance. Nevertheless, by using the Bayesian approach (i.e., updating the current data with previous data) it was found that there was a $99 \%$ probability that BMI among those with the Arg allele was higher than those without the Arg allele.

The frequency of the Arg allele in the present study was similar to that reported for the Australian population [39] and other Caucasian populations $[40,41]$, but lower than that of Asian populations [27,42-44]. To our knowledge, the present study is the first to investigate the association between ADRB3 genotypes and BMD and fracture risk in Caucasian population.

The present results suggest there was no statistically significant association between ADRB3 genotypes and BMD. This is consistent with previous findings in Japanese women $[27,38]$ (Table 6). It has been suggested that the association between ADRB3 and BMD are more likely to be found in obese individuals than in non-obese individuals. However, in the present study, the non-significant association between ADRB3 and BMD was observed in both obese and non-obese individuals (data not shown). 


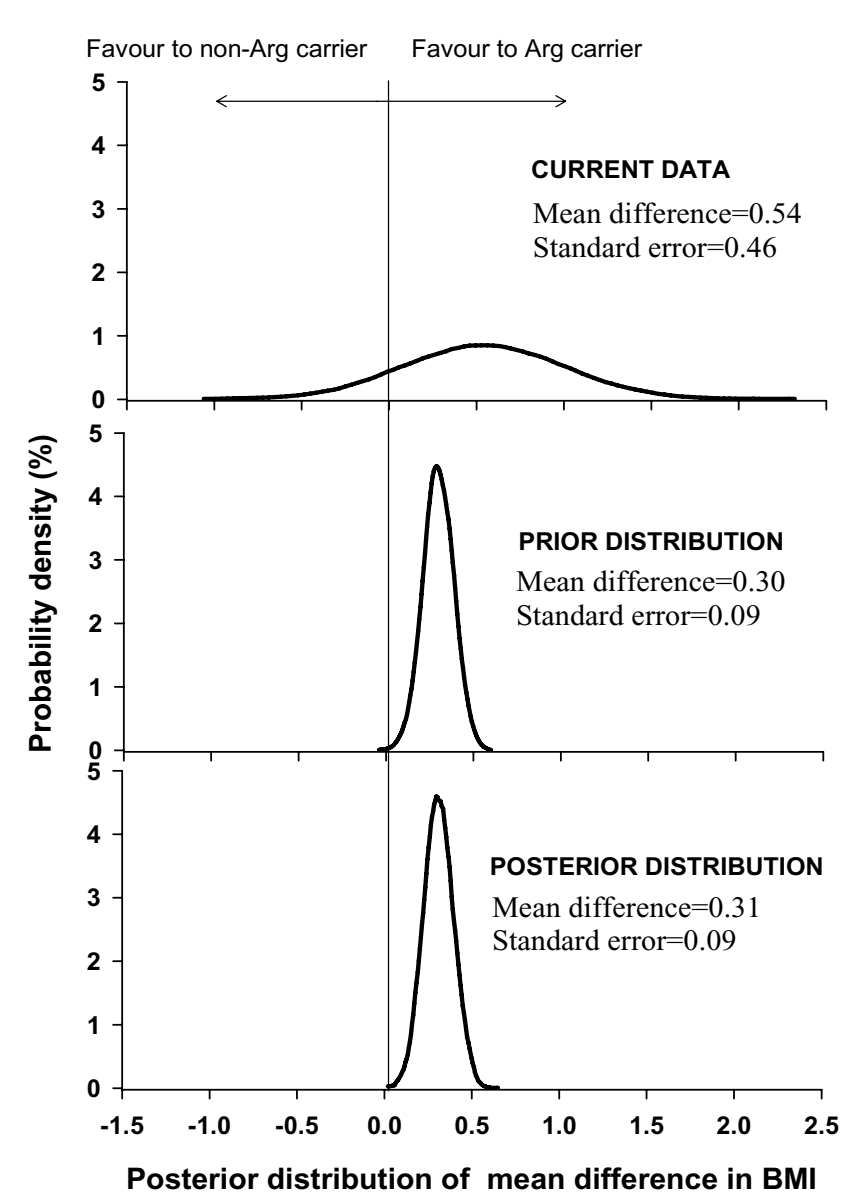

Figure I

Posterior distribution of mean difference in BMI $\left(\mathrm{kg} / \mathrm{m}^{2}\right)$ between Arg carriers and non-Arg carriers.

In this current study, no significant association was observed in either sex. However, while women with the Arg allele appeared to have lower risk of fracture, men with the Arg allele had increased risk of fracture. The reason for this opposite trend was not apparent; however, stochastic fluctuation can be a contributory factor.

BMD is largely determined by genetic factors [45], and as BMI is a strong predictor of BMD [14], we thus hypothesized that ADRB3, being a candidate gene for BMI, would have pleiotropic effect on both BMD and BMI. However, the present results did not support the hypothesis, and the effect of ADRB3 seemed to be BMI specific, and the effect of ADRB3 on BMI showed a $0.31 \mathrm{~kg} / \mathrm{m}^{2}$ difference between genotypes.

The present study was based on a relatively large sample size which has been followed up for a reasonably long period of time (up to 15 years), which allows more precise delineation of effect than smaller studies. Moreover, subjects in this study are of Caucasian background, and the present results are likely to be valid in similar populations of elderly Caucasians. However, a potential limitation is that with the low prevalence of the Arg allele in the ADRB3 gene there are small numbers of subjects with the $\mathrm{Arg} / \mathrm{Arg}$ genotype. Since fracture is a relatively rare event, the lack of fracture cases in individuals with Arg allele could limit the power of the study.

Furthermore, this study examined only one polymorphism which may not adequately capture the polymorphic variation within the gene, and hence limited the chance of finding an underlying association. There is also a lack of association studies investigating the relationship between ADRB3 genotypes and BMD, and no studies have investigated the association between ADRB3 genotypes and fracture risk, therefore no prior information could be drawn to reinforce our findings via the Bayesian approach.

\section{Conclusion}

In summary, the present data suggested that in elderly men and women, there is a weak positive association between Arg allele of the ADRB3 gene and BMI. However, no significant associations were observed between ADRB3 polymorphisms and BMD or fracture risk, and it seems unlikely that ADRB3 has a significant predictive value for osteoporotic fracture risk.

\section{Abbreviations}

All abbreviations are defined in the text.

\section{Competing interests}

Dr John Eisman who serves as a consultant and receives corporate appointment from Aventis, Eli Lilly and Company, Merck Sharp \& Dohme Ltd., Novartis, MPS Pharmaceuticals, Organon, Roche and Servier.

All other authors have neither financial nor non-financial competing interests that may be affected from the publication of the manuscript.

\section{Authors' contributions}

CYW and NDN obtained and analysed data, and drafted the manuscript. NM performed the genotyping and was initially involved in the conceptual discussion of the project. JRC had an active role in the conduct of the Dubbo Osteoporosis Epidemiology Study. JAE established the Dubbo Osteoporosis Epidemiology Study. TVN had an active role in the Dubbo Osteoporosis Epidemiology Study since its inception; he was involved in the study design, data analysis, and in the conceptual discussion of the project. All authors contributed to the last version of the manuscript. 
Table 2: ADRB3 genotype and BMD: Standardized regression coefficient from the multiple regression analyses

\begin{tabular}{|c|c|c|c|c|}
\hline & \multicolumn{2}{|c|}{ LSBMD } & \multicolumn{2}{|c|}{ FNBMD } \\
\hline & Coefficient & $P$ value & Coefficient & $P$ value \\
\hline \multicolumn{5}{|l|}{ Women } \\
\hline Age & -0.040 & 0.380 & -0.344 & $<0.01$ \\
\hline BMI & 0.366 & $<0.01$ & 0.382 & $<0.01$ \\
\hline Smoking & $-0.04 I$ & 0.37 & -0.087 & 0.03 \\
\hline Calcium intake & -0.018 & 0.69 & 0.050 & 0.23 \\
\hline Physical activity & 0.140 & $<0.01$ & 0.035 & 0.40 \\
\hline $\mathrm{ADRB}^{\mathrm{a}}$ & 0.044 & 0.33 & 0.046 & 0.26 \\
\hline $\mathrm{R}^{2}$ & 0.162 & & 0.302 & \\
\hline \multicolumn{5}{|l|}{ Men } \\
\hline Age & -0.018 & 0.78 & -0.187 & $<0.01$ \\
\hline BMI & 0.231 & $<0.01$ & 0.240 & $<0.01$ \\
\hline Smoking & -0.104 & 0.09 & -0.149 & $<0.01$ \\
\hline Calcium intake & 0.091 & 0.14 & 0.048 & 0.01 \\
\hline Physical activity & 0.124 & 0.05 & 0.036 & 0.43 \\
\hline $\mathrm{ADRB}^{\mathrm{a}}$ & 0.001 & 0.99 & 0.003 & 0.60 \\
\hline $\mathrm{R}^{2}$ & 0.074 & & 0.120 & \\
\hline
\end{tabular}

LSBMD, lumbar spine bone mineral density; FNBMD, femoral neck bone mineral density.

$\mathrm{R}^{2}$ : coefficient of determination; proportion of variance of BMD (LSBMD or FNBMD) accounted for by all the factors in the model. aNon-Arg allele carrier and Arg allele carrier.

Table 3: Baseline characteristics of subjects with and without fracture

\begin{tabular}{|c|c|c|c|c|c|}
\hline & Any fracture & Non-fracture & Mean difference $(95 \% \mathrm{Cl})$ & $\mathrm{SD}^{\mathrm{a}}$ & $P$ value \\
\hline \multicolumn{6}{|l|}{ Women } \\
\hline Number of subjects & 173 & 273 & & & \\
\hline Age $(y)$ & $72 \pm 8$ & $70 \pm 7$ & $1.86(0.46,3.226)$ & 0.27 & $<0.01$ \\
\hline Weight (kg) & $63 \pm 12$ & $66 \pm 12$ & $-2.76(-5.14,-0.38)$ & -0.25 & 0.03 \\
\hline Height (cm) & $159 \pm 7$ & $160 \pm 6$ & $-0.89(-2.06,0.27)$ & -0.16 & 0.13 \\
\hline $\mathrm{BMI}\left(\mathrm{kg} / \mathrm{m}^{2}\right)$ & $25 \pm 4$ & $26 \pm 5$ & $-0.88(-1.76,0)$ & -0.22 & 0.05 \\
\hline Ca intake (mg/day) & $640 \pm 379$ & $648 \pm 364$ & $-7.70(-78.93,63.52)$ & -0.02 & 0.83 \\
\hline Physical activity (METs) & $83 \pm 32$ & $79 \pm 27$ & $3.67(-1.99,9.32)$ & 0.14 & 0.20 \\
\hline Femoral neck BMD $\left(\mathrm{g} / \mathrm{cm}^{2}\right)$ & $0.72 \pm 0.12$ & $0.80 \pm 0.13$ & $-0.07(-0.10,-0.05)$ & -0.63 & $<0.01$ \\
\hline Lumbar spine BMD $\left(\mathrm{g} / \mathrm{cm}^{2}\right)$ & $0.95 \pm 0.17$ & $1.04 \pm 0.19$ & $-0.09(-0.12,-0.05)$ & -0.49 & $<0.01$ \\
\hline Age of menopause $(y)$ & $46 \pm 8$ & $47 \pm 7$ & $-1.46(-2.86,-0.06)$ & -0.14 & 0.04 \\
\hline Current/ex smoker $\mathrm{b}, \mathrm{c}$ & $46(26.6)$ & $82(30.0)$ & & & 0.43 \\
\hline \multicolumn{6}{|l|}{ Men } \\
\hline Number of subjects & 49 & 216 & & & \\
\hline Age $(y)$ & $73 \pm 6$ & $69 \pm 6$ & $3.54(1.73,5.36)$ & 0.67 & $<0.01$ \\
\hline Weight (kg) & $75 \pm 11$ & $79 \pm 12$ & $-4.05(-7.81,-0.29)$ & -0.34 & 0.03 \\
\hline Height $(\mathrm{cm})$ & $|7| \pm 7$ & $174 \pm 6$ & $-2.75(-4.82,-0.69)$ & -0.48 & 0.01 \\
\hline BMI $\left(\mathrm{kg} / \mathrm{m}^{2}\right)$ & $25 \pm 3$ & $26 \pm 4$ & $-0.54(-1.64,0.55)$ & -0.26 & 0.33 \\
\hline Ca intake (mg/day) & $693 \pm 475$ & $663 \pm 330$ & $29.77(-83.66,143.19)$ & 0.08 & 0.61 \\
\hline Physical activity (METs) & $84 \pm 53$ & $73 \pm 47$ & $11.19(-4.59,26.98)$ & 0.23 & 0.16 \\
\hline Femoral neck BMD $\left(\mathrm{g} / \mathrm{cm}^{2}\right)$ & $0.85 \pm 0.13$ & $0.94 \pm 0.15$ & $-0.09(-0.14,-0.05)$ & -0.61 & $<0.01$ \\
\hline Lumbar spine BMD $\left(\mathrm{g} / \mathrm{cm}^{2}\right)$ & $1.14 \pm 0.20$ & $1.28 \pm 0.21$ & $-0.14(-0.21,-0.07)$ & -0.67 & $<0.01$ \\
\hline Current/ex smoker b, c & $33(67.3)$ & $1 \mid 4(52.8)$ & & & 0.06 \\
\hline
\end{tabular}

Values are mean $\pm S D$, otherwise specified; $P$ values are calculated using unpaired $t$-test, otherwise specified. BMI, body mass index; $C a$, calcium; METs, metabolic equivalents;

a Standardized difference; ${ }^{b}$ Chi-square test; $\mathrm{c} N(\%)$. 
Table 4: Frequency of fracture types stratified by $\beta 3$-Adrenergic Receptor genotype

\begin{tabular}{|c|c|c|c|}
\hline & \multicolumn{2}{|c|}{ Genotype } & \multirow[t]{3}{*}{$P$ value } \\
\hline & $\operatorname{Trp} / \operatorname{Trp}$ & Arg/Arg+ & \\
\hline & & $\operatorname{Trp} / \operatorname{Arg}$ & \\
\hline Women (N) & 385 & 61 & \\
\hline Non-fracture & $232(60.3)$ & $41(67.2)$ & \\
\hline Any fracture & $153(39.7)$ & $20(32.8)$ & 0.30 \\
\hline Hip fracture & $37(13.8)$ & $4(8.9)$ & $0.66^{\mathrm{b}}$ \\
\hline Vertebral fracture & $53(18.6)$ & $5(10.9)$ & 0.23 \\
\hline Wrist/forearm & 54 (18.9) & $5(10.9)$ & 0.21 \\
\hline Men (N) & 224 & 41 & \\
\hline Non-fracture & $184(82.1)$ & $32(78.1)$ & \\
\hline Any fracture & $40(17.9)$ & $9(22.0)$ & 0.53 \\
\hline Hip fracture & $8(4.2)$ & $2(5.9)$ & $0.66^{b}$ \\
\hline Vertebral fracture & $17(8.5)$ & $5(13.5)$ & 0.33 \\
\hline Wrist/forearm & $3(1.6)$ & I (3.0) & $0.49 \mathrm{~b}$ \\
\hline
\end{tabular}

aChi-square test, otherwise specified; bFisher's exact test

Table 5: Relationship between $\beta 3$-Adrenergic Receptor genotypes and fracture risk

\begin{tabular}{|c|c|c|c|c|}
\hline & Any fracture & Hip fracture & Vertebral fracture & Wrist/forearmb \\
\hline \multicolumn{5}{|l|}{ Women } \\
\hline ADRB3 unadjusted ${ }^{a}$ & $0.74(0.42,1.31)$ & $0.66(0.23,1.92)$ & $0.56(0.21,1.46)$ & $0.55(0.21,1.43)$ \\
\hline Adjusted for age (I) & $0.72(0.40,1.28)$ & $0.66(0.22,1.96)$ & $0.55(0.21,1.43)$ & $0.54(0.21,1.42)$ \\
\hline Adjusted for FNBMD (2) & $0.84(0.46,1.55)$ & $0.83(0.25,2.77)$ & $0.62(0.24,1.64)$ & $0.61(0.23,1.61)$ \\
\hline Adjusted for BMI (3) & $0.76(0.42,1.37)$ & $0.82(0.27,2.44)$ & $0.60(0.23,1.56)$ & $0.57(0.22,1.50)$ \\
\hline Adjusted for (I) and (2) & $0.84(0.45,1.55)$ & $0.78(0.23,2.61)$ & $0.60(0.23,1.58)$ & $0.61(0.23,1.60)$ \\
\hline Adjusted for (I) and (3) & $0.74(0.41,1.33)$ & $0.70(0.23,2.16)$ & $0.57(0.22,1.5 \mathrm{I})$ & $0.56(0.22,1.48)$ \\
\hline $\begin{array}{l}\text { Adjusted for (I) and (2) } \\
\text { and (3) }\end{array}$ & $0.83(0.45,1.53)$ & $0.75(0.22,2.56)$ & $0.60(0.23,1.59)$ & $0.61(0.23,1.60)$ \\
\hline \multicolumn{5}{|l|}{ Men } \\
\hline ADRB3 unadjusted ${ }^{a}$ & $1.29(0.57,2.92)$ & $1.39(0.28,6.76)$ & $1.69(0.59,4.88)$ & $1.840 .19,18.18)$ \\
\hline Adjusted for age (I) & $1.57(0.68,3.65)$ & $2.87(0.50,16.39)$ & $2.03(0.69,6.02)$ & - \\
\hline Adjusted for FNBMD (2) & $1.25(0.52,3.04)$ & $1.47(0.29,7.46)$ & $\mathrm{I} .88(0.62,5.7 \mathrm{I})$ & - \\
\hline Adjusted for BMI (3) & $1.28(0.56,2.89)$ & $1.34(0.27,6.58)$ & $1.66(0.57,4.78)$ & - \\
\hline Adjusted for (I) and (2) & $1.47(0.60,3.62)$ & $3.03(0.52,17.54)$ & $2.15(0.69,6.67)$ & - \\
\hline Adjusted for (I) and (3) & $1.57(0.67,3.65)$ & $2.85(0.50,16.39)$ & $2.02(0.68,6.02)$ & - \\
\hline $\begin{array}{l}\text { Adjusted for (I) and (2) } \\
\text { and (3) }\end{array}$ & $1.46(0.59,3.62)$ & $2.88(0.48,7.24)$ & $2.15(0.69,6.67)$ & - \\
\hline
\end{tabular}

Values are Odds ratio and $95 \% \mathrm{Cl}$;

aArg-allele carriers were considered the risk factor in the model and Trp/Trp genotype was the reference group.

badjusted OR was not calculated for wrist/forearm fracture in men due to small number of fracture. 
Table 6: $\beta 3$ AR genotypes and bone mineral density: summary of previous and present studies

\begin{tabular}{|c|c|c|c|c|}
\hline First Author and genotypes & $\mathrm{N}(\%)$ & $\begin{array}{c}\text { Femoral neck BMD (mean; } \\
\text { SD) }\end{array}$ & $\begin{array}{l}\text { Lumbar spine BMD (mean; } \\
\text { SD) }\end{array}$ & $\begin{array}{c}\text { Total body BMD (mean; } \\
\text { SD) }\end{array}$ \\
\hline \multicolumn{5}{|l|}{ Ogawa et al. [38] ${ }^{a}$} \\
\hline Trp/Trp and Trp/Arg & $267(95.4)$ & NA & $0.145(1.36)$ & $0.432(0.93)$ \\
\hline Arg/Arg & $13(4.6)$ & NA & $0.179(2.11)$ & $-0.135(0.93)$ \\
\hline P-value & & NA & NS & 0.033 \\
\hline \multicolumn{5}{|l|}{ Kasumata et al. [27] b } \\
\hline Trp/Trp and Trp/Arg & $142(97.6)$ & NA & NA & NA \\
\hline Arg/Arg & $3(2.4)$ & NA & NA & NA \\
\hline P-value & & NS & NS & NA \\
\hline \multicolumn{5}{|l|}{ The present study } \\
\hline $\operatorname{Trp} / \operatorname{Trp}$ & $385(86.3)$ & $0.76(0.13)$ & $1.00(0.18)$ & NA \\
\hline Trp/Arg and Arg/Arg & $61(13.7)$ & $0.79(0.13)$ & $\mathrm{I} .04(0.2 \mathrm{I})$ & NA \\
\hline P-value & & 0.238 & 0.113 & NA \\
\hline
\end{tabular}

NA, not available; NS, non-significant. aValues were shown as Z-scores BMD. b Data were not shown; the authors only stated in text: "No association was demonstrated between the ER, CaSR or $33-A R$ genotypes and BMD, either alone or in relation to other polymorphisms".

\section{Acknowledgements}

We gratefully acknowledge the assistance of Sr Janet Watters and Donna Reeves for the interview, data collection and measurement bone mineral density. We also appreciate the invaluable help of the staff of Dubbo base hospital. This works has been partly supported by the National Health and Medical Research Council of Australia and untied educational grants from GE-Lunar, Merck Australia, Eli Lilly International and Aventis Australia.

\section{References}

I. Flegal KM, Graubard BI, Williamson DF, Gail MH: Excess deaths associated with underweight, overweight, and obesity. JAMA 2005, 293(15): |86|-1867.

2. Andreyeva T, Sturm R, Ringel JS: Moderate and severe obesity have large differences in health care costs. Obes Res 2004, I 2(I 2): 1936-1943.

3. Kumanyika S, Jeffery RW, Morabia A, Ritenbaugh C, Antipatis VJ: Obesity prevention: the case for action. Int J Obes Relat Metab Disord 2002, 26(3):425-436.

4. Kanis JA, Melton LJ, Christiansen C, Johnston CC, Khaltaev N: The diagnosis of osteoporosis. J Bone Miner Res I994, 9(8): I |37-I | 4 |

5. Hedley AA, Ogden CL, Johnson CL, Carroll MD, Curtin LR, Flegal KM: Prevalence of overweight and obesity among US children, adolescents, and adults, 1999-2002. JAMA 2004, 29 I(23):2847-2850.

6. Pruzansky ME, Turano M, Luckey M, Senie R: Low body weight as a risk factor for hip fracture in both black and white women. J Orthop Res 1989, 7(2): 192-197.

7. Turner LW, Wang MQ, Fu Q: Risk factors for hip fracture among southern older women. South Med J 1998, 9I(6):533-540.

8. del Puente A, Postiglione A, Esposito-del Puente A, Carpinelli A, Romano M, Oriente P: Peripheral body fat has a protective role on bone mineral density in elderly women. Eur J Clin Nutr 1998, 52(9):690-693.

9. Margolis KL, Ensrud KE, Schreiner PJ, Tabor HK: Body size and risk for clinical fractures in older women. Study of Osteoporotic Fractures Research Group. Ann Intern Med 2000, 133(2): 123-127.

10. Shiraki M, Ito H, Fujimaki H, Higuchi T: Relation between body size and bone mineral density with special reference to sex hormones and calcium regulating hormones in elderly females. Endocrinol Jpn 1991, 38(4):343-349.

II. Nguyen ND, Pongchaiyakul C, Center JR, Eisman JA, Nguyen TV: Abdominal fat and hip fracture risk in the elderly: The Dubbo Osteoporosis Epidemiology Study. BMC Musculoskelet Disord 2005, 6(I): II.
12. Orozco P, Nolla JM: Associations between body morphology and bone mineral density in premenopausal women. EurJ Epidemiol 1997, 13(8):919-924.

13. Martinez Diaz-Guerra G, Hawkins F, Rapado A, Ruiz Diaz MA, DiazCuriel M: Hormonal and anthropometric predictors of bone mass in healthy elderly men: major effect of sex hormone binding globulin, parathyroid hormone and body weight. Osteoporos Int 200I, I 2(3): 178-I84.

14. Blum M, Harris SS, Must A, Phillips SM, Rand WM, Dawson-Hughes $B$ : Weight and body mass index at menarche are associated with premenopausal bone mass. Osteoporos Int 200I, I 2(7):588-594.

15. Christian JC, Yu PL, Slemenda CW, Johnston CCJ: Heritability of bone mass: a longitudinal study in aging male twins. Am J Hum Genet 1989, 44(3):429-433.

16. Pocock NA, Eisman JA, Hopper JL, Yeates MG, Sambrook PN, Eberl $\mathrm{S}$ : Genetic determinants of bone mass in adults. A twin study. J Clin Invest 1987, 80(3):706-7I0.

17. Nguyen TV, Howard GM, Kelly PJ, Eisman JA: Bone mass, lean mass, and fat mass: same genes or same environments? $\mathrm{Am}$ J Epidemiol 1998, 147(1):3-16.

18. Nath SK, Chakravarti A, Chen CH, Cooper R, Weder A, Schork NJ: Segregation analysis of blood pressure and body mass index in a rural US community. Hum Biol 2002, 74(I): I I-23.

19. Allison DB, Kaprio J, Korkeila M, Koskenvuo M, Neale MC, Hayakawa $K$ : The heritability of body mass index among an international sample of monozygotic twins reared apart. Int J Obes Relat Metab Disord 1996, 20(6):50I-506.

20. Flicker L, Hopper JL, Rodgers L, Kaymakci B, Green RM, Wark JD: Bone density determinants in elderly women: a twin study. $J$ Bone Miner Res 1995, I0( I I):1607-16I3.

21. Kannus P, Palvanen M, Kaprio J, Parkkari J, Koskenvuo M: Genetic factors and osteoporotic fractures in elderly people: prospective $\mathbf{2 5}$ year follow up of a nationwide cohort of elderly Finnish twins. Bmj 1999, 319(7221): I334-I337.

22. Nguyen TV, Esteban LM, White CP, Grant SF, Center JR, Gardiner EM, Eisman JA: Contribution of the collagen I alphal and vitamin $D$ receptor genes to the risk of hip fracture in elderly women. J Clin Endocrinol Metab 2005, 90( I 2):6575-6579.

23. Mann V, Ralston SH: Meta-analysis of COLIAI SpI polymorphism in relation to bone mineral density and osteoporotic fracture. Bone 2003, 32(6):7||-7|7.

24. Takeuchi T, Tsuboi T, Arai M, Togari A: Adrenergic stimulation of osteoclastogenesis mediated by expression of osteoclast differentiation factor in MC3T3-EI osteoblast-like cells. Biochem Pharmacol 200I, 6 I (5):579-586.

25. Moore RE, Smith CK, Bailey CS, Voelkel EF, Tashjian AHJ: Characterization of beta-adrenergic receptors on rat and human 
osteoblast-like cells and demonstration that beta-receptor agonists can stimulate bone resorption in organ culture. Bone Miner 1993, 23(3):301-315.

26. Fujisawa T, Ikegami $H$, Kawaguchi $Y$, Ogihara $T$ : Meta-analysis of the association of Trp64Arg polymorphism of beta 3-adrenergic receptor gene with body mass index. J Clin Endocrinol Metab 1998, 83(7):244|-2444.

27. Katsumata K, Nishizawa K, Unno A, Fujita Y, Tokita A: Association of gene polymorphisms and bone density in Japanese girls. J Bone Miner Metab 2002, 20(3): I64- I69.

28. Center JR, Nguyen TV, Schneider D, Sambrook PN, Eisman JA: Mortality after all major types of osteoporotic fracture in men and women: an observational study. Lancet 1999, 353(9 | 56):878-882.

29. Jones G, Nguyen T, Sambrook PN, Kelly PJ, Gilbert C, Eisman JA: Symptomatic fracture incidence in elderly men and women: the Dubbo Osteoporosis Epidemiology Study (DOES). Osteoporos Int 1994, 4(5):277-282.

30. Nguyen TV, Eisman JA, Kelly PJ, Sambrook PN: Risk factors for osteoporotic fractures in elderly men. Am J Epidemiol 1996, | 44(3):255-263.

31. Nguyen TV, Center JR, Eisman JA: Osteoporosis in elderly men and women: effects of dietary calcium, physical activity, and body mass index. J Bone Miner Res 2000, I 5(2):322-33I.

32. Clement K, Vaisse C, Manning BS, Basdevant A, Guy-Grand B, Ruiz J, Silver KD, Shuldiner AR, Froguel P, Strosberg AD: Genetic variation in the beta 3-adrenergic receptor and an increased capacity to gain weight in patients with morbid obesity. $N$ Engl J Med 1995, 333(6):352-354.

33. SPSS Inc.: SPSS I 3.0 Base User's Guide. Chicago, IL , SPSS Inc.; 2004.

34. Matthews RAJ: Facts versus factions: The use and abuse of subjectivity in scientific research: Barton, Cambridge, UK. 1998.

35. Spiegelhalter DJ, Abrams KR, Myles JP: Bayesian Approaches to Clinical Trials and Health-Care Evaluation. West Sussex, England , John Wiley \& Sons Ltd.; 2004.

36. SAS Institute Inc.: Base SAS 9.I.3 Procedures Guide, Volumes I-4. In Base SAS 9.I.3 (TSIM3) edition. Cary, NC, USA, SAS Publishing; 2004.

37. Leonard MB, Shults J, Wilson BA, Tershakovec AM, Zemel BS: Obesity during childhood and adolescence augments bone mass and bone dimensions. Am J Clin Nutr 2004, 80(2):5 I4-523.

38. Ogawa S, Emi M, Shiraki M, Hosoi T, Orimo H, Ouchi Y, Inoue S: Association of amino acid variation (Trp64Arg) in the beta3adrenergic receptor gene with bone mineral density. Geriatrics and Gerontology International 2002, 2(3): I38-I42.

39. Kurabayashi T, Carey DG, Morrison NA: The beta 3-adrenergic receptor gene Trp64Arg mutation is overrepresented in obese women. Effects on weight, BMI, abdominal fat, blood pressure, and reproductive history in an elderly Australian population. Diabetes 1996, 45(I0): I358-1363.

40. Li LS, Lonnqvist F, Luthman H, Arner P: Phenotypic characterization of the Trp64Arg polymorphism in the beta 3-adrenergic receptor gene in normal weight and obese subjects. Diabetologia 1996, 39(7):857-860.

4I. Oksanen L, Mustajoki P, Kaprio J, Kainulainen K, Janne O, Peltonen L, Kontula K: Polymorphism of the beta 3-adrenergic receptor gene in morbid obesity. Int J Obes Relat Metab Disord 1996, 20(12): 1055-106I.

42. Hao K, Peng S, Xing H, Yu Y, Huang A, Hong $X$, Wang $Y$, Chen C, Wang B, Zhang X, Liu J, Zhu G, Huo Y, Chen D, Zhao X, Ronnenberg $\mathrm{A}, \mathrm{Wu} \mathrm{D}, \mathrm{Niu} \mathrm{T}, \mathrm{Xu} \mathrm{X}$ : beta(3) Adrenergic receptor polymorphism and obesity-related phenotypes in hypertensive patients. Obes Res 2004, I 2(I): I25-130.

43. Matsushita H, Kurabayashi T, Tomita M, Kato N, Tanaka K: Effects of uncoupling protein I and beta3-adrenergic receptor gene polymorphisms on body size and serum lipid concentrations in Japanese women. Maturitas 2003, 45(I):39-45.

44. Kadowaki H, Yasuda K, Iwamoto K, Otabe S, Shimokawa K, Silver K, Walston J, Yoshinaga $\mathrm{H}$, Kosaka K, Yamada N, et al:: A mutation in the beta 3-adrenergic receptor gene is associated with obesity and hyperinsulinemia in Japanese subjects. Biochem Biophys Res Commun 1995, 2 I 5(2):555-560.

45. Livshits G, Deng HW, Nguyen TV, Yakovenko K, Recker RR, Eisman JA: Genetics of bone mineral density: evidence for a major pleiotropic effect from an intercontinental study. J Bone Miner Res 2004, 19(6):914-923.

\section{Pre-publication history}

The pre-publication history for this paper can be accessed here:

http://www.biomedcentral.com/1471-2350/7/57/prepub
Publish with Biomed Central and every scientist can read your work free of charge

"BioMed Central will be the most significant development for disseminating the results of biomedical research in our lifetime. "

Sir Paul Nurse, Cancer Research UK

Your research papers will be:

- available free of charge to the entire biomedical community

- peer reviewed and published immediately upon acceptance

- cited in PubMed and archived on PubMed Central

- yours - you keep the copyright

Submit your manuscript here:

http://www.biomedcentral.com/info/publishing_adv.asp
BioMedcentral 